\title{
AKTIVITAS ANTIOKSIDAN DAN TINGKAT PENERIMAAN KONSUMEN PADA MINUMAN INSTAN YANG DIPERKAYA DENGAN EKSTRAK Sargassum polycystum
}

\author{
Antioxidant Activity and Consumer Preference of Instant Drink Enriched with Sargassum polycystum Extract
}

\author{
Amir Husni, Dewi Ariani, Siti Ari Budhiyanti
}

Jurusan Perikanan, Fakultas Pertanian, Universitas Gadjah Mada, Jl. Flora Gedung A4, Bulaksumur, Yogyakarta 55281

Email: a-husni@ugm.ac.id

\begin{abstract}
ABSTRAK
Minuman instan ekstrak Sargassum polycystum rasa jahe merupakan produk olahan rumput laut dalam bentuk serbuk yang sebelumnya telah mengalami proses pengeringan, ekstraksi, kokristalisasi dan pengayakan menjadi serbuk. Tujuan penelitian ini ialah menghasilkan formula minuman instan rumput laut yang mempunyai aktivitas antioksidan dan disukai konsumen. Formula yang digunakan pada penelitian ini terdiri dari ekstrak etanolik S. polycystum, gula dan jahe dengan komposisi kontrol (0:3:1), formula $1(0,1: 2,9: 1)$, formula $2(0,2: 2,8: 1)$, formula $3(0,3: 2,7: 1)$, formula $4(0,4: 2,6: 1)$, formula $5(0,5: 2,5: 1)$, dan formula $6(0,6: 2,4: 1)$. Hasil penelitian menunjukkan bahwa minuman instan mempunyai nilai aktivitas antioksidan 25,7-65,41\%, total fenol 27,74-100,36 mg GAE/gram, total gula 76,13-87,18\%, kadar air 0,44-1,99\%, kadar abu 0,06-11,54\% dan nilai hedonis warna 2,4-3,2 (tidak suka - suka); aroma 1,29-3,66 (sangat tidak suka - suka); dan rasa 1,32-3,59 (sangat tidak suka - suka).
\end{abstract}

Kata kunci: Minuman instan, Sargassum polycystum, jahe, antioksidan

\begin{abstract}
Instant drink of ethanolic extract Sargassum polycystum with ginger flavor was made from seaweds which was processed into powder and have undergone processes of drying, extraction, cocrystalization, and sieving into powder. The objective of this research was to produce a formula of the seaweed instant drink which has a high antioxidant activity and is preferred by consumers. The formula that was used in this research waere ethanolic extract of $S$. polycystum, sugar and ginger. The compostion of formula including control $(0: 3: 1)$, formula $1(0.1: 2.9: 1)$, formula $2(0.2: 2.8: 1)$, formula $3(0.3: 2.7: 1)$, formula $4(0.4: 2.6: 1)$, formula $5(0.5: 2.5: 1)$, and formula $6(0.6: 2.4: 1)$. The result showed that the instant drink contained the value of antioxidant activity by $25.70-65.41 \%$, total fenol of 27.74-100.36 mg GAE/gram, water levels of $0.44-1.99 \%$, ash levels of $0.06-11.54 \%$ and the value of hedonic color 2,4-3,2(don't like - like); hedonic flavor 1.29-3.66 (very don't like - like); and hedonic taste 1.32-3.59 (very don't like - like).
\end{abstract}

Keywords: Instant drink, Sargassum polycystum, ginger, antioxidant

\section{PENDAHULUAN}

Pada era globalisasi sekarang ini, pola konsumsi masyarakat Indonesia umumnya berubah dari mengkonsumsi makanan alami menjadi makanan cepat saji yang kaya akan lemak dan radikal bebas (Fagbemi dkk., 2013). Radikal bebas adalah molekul yang tidak stabil dan sangat reaktif karena mengandung satu atau lebih elektron tidak berpasangan pada orbital terluarnya, sehingga untuk mencapai kestabilan, radikal bebas akan bereaksi dengan molekul disekitarnya untuk memperoleh pasangan elektron (Rohmatussolihat, 2009). Adanya radikal bebas dalam tubuh dapat menimbulkan penyakit degeneratif seperti diabetes melitus dan penyakit lainnya seperti penyempitan pembuluh darah, jantung koroner, stroke, dan kanker (Kang dkk., 2010).

Upaya pencegahan penyakit diabetes melitus, penyempitan pembuluh darah, jantung koroner, stroke, dan kanker dapat dilakukan dengan mengatur konsumsi zat gizi yang masuk ke dalam tubuh manusia, salah satunya dengan mengkonsumsi produk pangan fungsional berupa makanan atau minuman yang mengandung antioksidan (Marsono, 2008). Antioksidan adalah senyawa kimia yang dapat menyumbangkan satu atau lebih elektron kepada radikal bebas, sehingga radikal bebas tersebut dapat diredam (Zubia dkk., 2009). 
Pangan fungsional adalah golongan makanan atau minuman yang mengandung bahan-bahan yang diperkirakan dapat meningkatkan status kesehatan atau dapat mencegah penyakit tertentu (Tangkeallo dan Widyaningsih, 2014). Salah satu produk pangan fungsional diantaranya berupa minuman serbuk instan (Fagbemi dkk., 2013). Upaya pembuatan minuman kesehatan instan terus dilakukan antara lain dengan melakukan berbagai formulasi bahan-bahan alami yang mengandung antioksidan tinggi. Salah satu tumbuhan yang banyak mengandung antioksidan ialah alga cokelat Sargassum sp (Septiana dan Asnani, 2013). Senyawa antioksidan potensial dari alga cokelat yang telah berhasil diidentifikasi antara lain fukosantin, astasantin, karotenoid, fenolik, flavonoid, dan tanin yang bermanfaat sebagai antioksidan, antimutagenik, anti koagulan, anti tumor, dan metabolisme lipid (Kang dkk., 2010).

Penelitian mengenai pemanfaatan Sargassum sp. dalam pangan telah dilakukan, salah satunya dalam pembuatan minuman fungsional berbahan baku Sargassum sp. oleh Kusumawati (2007), namun masih terdapat permasalahan yaitu aroma khas rumput laut yang menyebabkan minuman beraroma amis. Penelitian ini dilakukan untuk memanfaatkan ekstrak Sargassum polycystum sebagai bahan tambahan dalam meningkatkan aktivitas antioksidan pada minuman jahe instan dengan citarasa yang disukai konsuman. Didalam penelitian ini dibuat serbuk instan untuk mempermudah pemanfaatan $S$. polycystum dari sisi pemakaiannya. Selain itu, serbuk instan sangat mudah dibuat minuman, hanya cukup menambahkan dengan air panas atau dingin sehingga lebih praktis dalam penyajiannya.

\section{METODE PENELITIAAN}

\section{Alat dan Bahan}

Peralatan utama yang digunakan dalam penelitian ini antara lain blender (Miyako), Erlenmeyer centrifuge (H-26F Kokusan), rotary evaporator vacuum (Laborota 4.000-Efficient Heidholph Instrument), freeze drier (Freezone 4,5 liter Freeze Dry Systems 7751030), dan timbangan (Simadzu BX-320D), incubator (Isuzu Incubator, SSJ-115 Japan). Bahan utama untuk pembuatan minuman instan adalah $S$. polycystum yang di peroleh dari pantai Pok Tunggal Gunungkidul. Jahe emprit dan gula pasir diperoleh dari pasar Demangan. Bahan-bahan lain yang digunakan antara lain ethanol 96\% (Fisher Scientific), reagen Folin Ciocalteu (Sigma-Aldrich), $\mathrm{Na}_{2} \mathrm{CO}_{3}$ (Difco), DPPH (Sigma-Aldrich), dan $\mathrm{HNO}_{3}$ (Difco).

\section{Preparasi dan Ekstraksi Sargassum polycystum}

Sampel S. polycystum segar yang diambil pada bulan Maret 2014 dikeringkan dengan menggunakan metode sebagaimana dijelaskan Zubia dkk. (2009), yaitu sampel dikeringanginkan pada suhu $20^{\circ} \mathrm{C}$ selama 6-7 hari. Sampelyang sudah kering selanjutnya digiling menjadi serbuk (saringan nomor 50) untuk diuji kandungan kadar airnya. Pembuatan ekstrak S. polycystum menggunakan metode Kang dkk. (2010), yaitu pembuatan ekstrak melalui proses ekstraksi, evaporasi, dan pengeringan. Serbuk kering ditimbang sebanyak 40 gram dan dimasukkan dalam erlenmeyer yang ditutup alumunium foil. Selanjutnya ditambahkan $375 \mathrm{ml}$ etanol 96\% atur $\mathrm{pH} 4$ dan distirer selama 4 jam lalu didiamkan selama 24 jam dan dipisahkan supernatannya. Supernatan dievaporasi $\left(40^{\circ} \mathrm{C}, 30\right.$ rpm) sampai pekat ( \pm 90 menit) kemudian difreeze drying dan disimpan pada suhu $-20^{\circ} \mathrm{C}$. Ekstrak kering beku ini digunakan sebagai ekstrak $S$. polycystum dalam pembuatan minuman instan.

\section{Preparasi dan Ekstraksi Jahe}

Tahap ini bertujuan untuk mendapatkan ekstrak jahe. Metode ekstraksi jahe dilakukan dengan cara: jahe dicuci bersih dan bagian yang busuk dibuang, dipotong kecilkecil kemudian diblender. Jahe yang sudah hancur, di saring sehingga terpisah antara filtrat dengan ampasnya. Filtrat jahe selanjutnya digunakan sebagai bahan pembuatan minuman instan.

\section{Pembuatan Minuman Instan Ekstrak Sargassum polycystum}

Pembuatan minuman instan menggunakan metode pembuatan serbuk dengan menggunakan teknik kokristalisasi (Che dkk., 1991). Proses pembuatannya yaitu ekstrak jahe ditambahkan gula pasir dimasak hingga membentuk kristal, didinginkan, dan ditambahkan bahan tambahan S. polycystum. Metode formulasi didasarkan pada hasil percobaan terhadap karakteristik mutu organoleptik dari minuman instan. Pengujian tingkat penerimaan konsumen terhadap minuman instan dilakukan dengan menggunakan metode Setyaningsih dkk. (2010). Hasil formulasi minuman instan berdasarkan pengujian threshold untuk penambahan ekstrak $S$. polycystum dalam minuman instan menghasilkan 6 formula dengan kontrol berupa minuman instan tanpa penambahan ekstrak $S$. polycystum (kontrol -) dan kontrol (+) yaitu asam askorbat dengan konsentrasi $3 \mathrm{mg} / \mathrm{ml}$. Formula minuman instan dengan penambahan ekstrak $S$. polycystum secara lengkap dapat dilihat pada Tabel 1 . 
Tabel. 1. Formulasi minuman instan ekstrak S. polycystum

\begin{tabular}{lccc}
\hline \multirow{2}{*}{ Perlakuan } & \multicolumn{3}{c}{ Formulasi bahan baku minuman instan } \\
& \multicolumn{3}{c}{ (gram) } \\
\cline { 2 - 4 } & Jahe & Gula & Ekstrak S.polycystum \\
\hline Kontrol (-) & 1 & 3 & 0 \\
Formula 1 & 1 & 2,9 & 0,1 \\
Formula 2 & 1 & 2,8 & 0,2 \\
Formula 3 & 1 & 2,7 & 0,3 \\
Formula 4 & 1 & 2,6 & 0,4 \\
Formula 5 & 1 & 2,5 & 0,5 \\
Formula 6 & 1 & 2,4 & 0,6 \\
Asam askorbat & - & - & - \\
(kontrol +) & & & \\
\hline
\end{tabular}

\section{Parameter Uji}

Parameter uji dalam penelitian ini meliputi: kadar air dengan metode thermogravimetri (BSN, 2006), aktivitas antioksidan didasarkan kemampuannya menangkap radikal bebas (radical scavenging activity) DPPH menurut metode yang dikembangkan oleh Zubia dkk. (2009), kadar total fenol dengan menggunakan metode Follin-Ciocalteu (Kang dkk., 2010), kadar total gula menggunakan metode Nelson Somogyi (Sudarmaji dkk., 1984), kadar abu dengan metode pengabuan (AOAC, 1925), dan uji sensoris berupa uji hedonik dengan metode sebagaimana dijelaskan oleh Setyaningsih dkk. (2010). Uji hedonik dilakukan menggunakan atribut warna, rasa, dan aroma minuman instan S. polycystum. Uji ini dilakukan oleh 80 orang panelis tidak terlatih dengan menilai parameter kesukaan warna, rasa, dan aroma dari masingmasing formulas minuman. Penilaian dilakukan dengan memberikan nilai $1-5(1=$ sangat tidak suka, $2=$ tidak suka, 3 $=$ agak suka, $4=$ suka, $5=$ sangat suka $)$.

\section{Analisis Data}

Analisis data dengan analisis sidik ragam (analysis of variance/ANOVA) pada tingkat kepercayaan 95\%. Apabila dari hasil ANOVA diperoleh beda nyata dilakukan uji lanjut HSD-Tukey (Gordon dan Gordon, 1994). Uji hedonik diolah secara statistika nonparametrik menngunakan Uji KruskalWallis pada tingkat kepercayaan 95\% dan jika ada beda nyata dilakukan uji lanjut Mann-Whitney (Daniel, 1989).

\section{HASIL DAN PEMBAHASAN}

\section{Aktivitas Antioksidan Bahan Baku Minuman Instan}

Aktivitas antioksidan bahan baku minuman instan dapat dilihat pada Gambar 1. Aktivitas antioksidan gula, jahe, dan ekstrak S. polycystum konsentrasi 5000 ppm menunjukkan hasil yang berbeda nyata $(\mathrm{p}<0,05)$ berturut-turut $8,15 \%$, $69,49 \%$, dan $66,46 \%$. Ibrahim dkk. (2014) menyebutkan bahwa aktivitas antioksidan ekstrak jahe merah sebesar $72,23 \%$. Rendahnya nilai aktivitas antioksidan yang diperoleh dalam penelitian ini dikarenakan menggunakan jenis jahe yang berbeda yaitu jahe emprit (Herold, 2007).

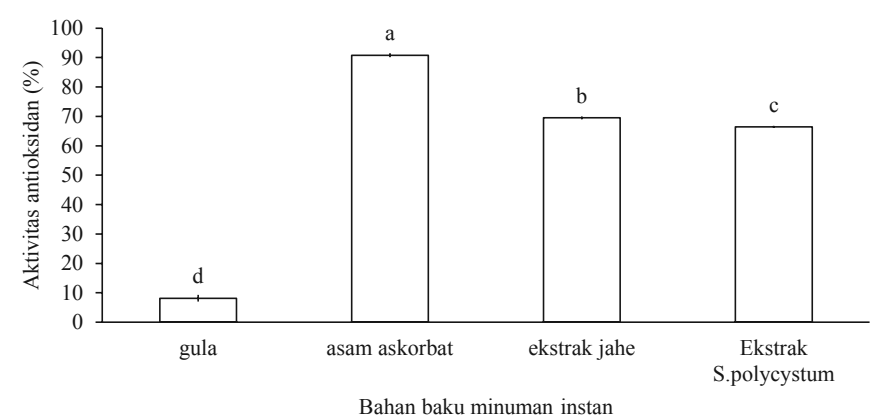

Gambar 1. Aktivitas antioksidan bahan baku minuman instan ekstrak S. polycystum

Keterangan: Tanda huruf yang berbeda menunjukkan ada beda nyata ( $\alpha$ $=0,05)$

Aktivitas antioksidan dari rumput laut dapat berbedabeda antara lain dipengaruhi oleh jenis, daerah asal, dan cara ekstraksi. Septiana dan Asnani (2013) menyebutkan bahwa ekstrak etanolik $S$. duplicatum mempunyai aktivitas antioksidan sebesar $72,73 \%$. Sementara itu ekstrak etanolik Sargassum sp. memiliki nilai aktivitas antioksidan sebesar 52,70-73,15\% (Kumar dkk., 2011).

\section{Aktivitas Antioksidan Minuman Instan}

Pengaruh variasi penambahan ekstrak S. polycystum terhadap aktivitas antioksidan minuman instan dapat dilihat pada Gambar 2. Hasil analisis menunjukkan bahwa aktivitas antioksidan minuman instan dipengaruhi oleh variasi penambahan ekstrak $S$. polycystum $(\mathrm{p}<0,05)$. Aktivitas antioksidan minuman kontrol (-) dengan formula gula dan jahe berbeda nyata dengan minuman instan yang diberi penambahan ekstrak $S$. polycystum dan asam askorbat $(\mathrm{p}<0,05)$. Terdapatnya aktivitas antioksidan dalam perlakuan kontrol dengan penambahan jahe, dikarenakan jahe memiliki senyawa aktif sebagai antioksidan berupa gingerol (Balachandran dkk., 2006). Aktivitas antioksidan bahan baku gula dan jahe sebelum dilakukan pembuatan minuman instan berturut-turut sebesar $8,15 \%$, dan $69,49 \%$ dan setelah menjadi minuman instan aktivitas antioksidannya menjadi $25,70 \%$. Penurunan aktivitas antioksidan jahe dapat terjadi karena adanya suhu tinggi. Ibrahim dkk. (2014) melaporkan bahwa kadar gingerol dalam jahe dapat mengalami penurunan selama 
proses pengeringan menggunakan sistem suhu pemanasan yang tinggi sehingga aktivitas antioksidannya juga menurun.

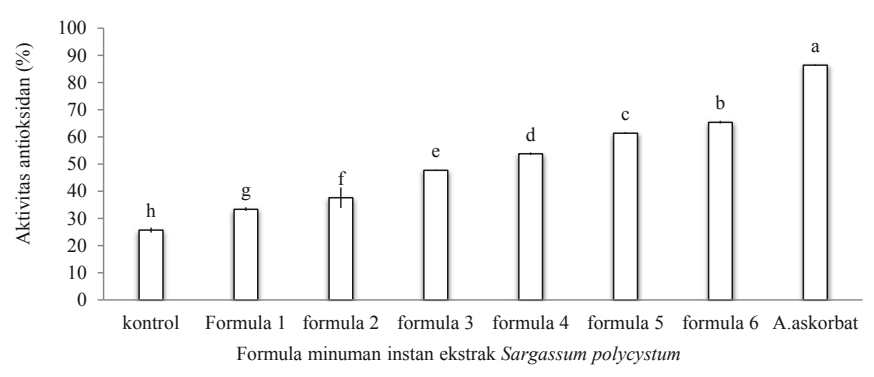

Gambar 2. Pengaruh formulasi penambahan ekstrak S. polycystum terhadap aktivitas antioksidan minuman instan (3000 ppm)

Keterangan: Tanda huruf yang berbeda menunjukkan ada beda nyata ( $\alpha$ $=0,05$ )

Aktivitas antioksidan yang terkandung didalam minuman instan dengan penambahan ekstrak $S$. polycystum merupakan gabungan aktivitas antioksidan dari gula, jahe, dan ekstrak $S$. polycystum. Penambahan ekstrak S. polycystum semakin tinggi meningkatkan nilai aktivitas antioksidan. Erminawati dan Naufalin (2014) menyatakan semakin besar konsentrasi ekstrak rumput laut yang diberikan maka semakin kuat aktivitas antioksidannya. Peningkatan aktivitas antioksidan dalam minuman instan dikarenakan ekstrak $S$. polycystum berfungsi sebagai antioksidan alami kaya akan senyawa fenol. Komponen fenol mampu menghambat reaksi oksidasi dan menangkap radikal bebas karena mempunyai gugus hidroksil (Prasetyaningrum dan Baskara, 2012). Tangkeallo dan Widyaningsih (2014) malaporkan bahwa aktivitas antioksidan minuman jahe dengan penambahan ekstrak miana berkorelasi positif dengan nilai total fenolnya. Semakin tinggi aktivitas antioksidan maka semakin tinggi kandungan senyawa fenolnya.

\section{Kadar Total Fenol}

Hasil pengujian total fenol minuman instan dengan penambahan ekstrak $S$. polycystum dapat dilihat pada Gambar 3. Gula memiliki kadar total fenol lebih rendah bila dibandingkan dengan minuman instan yaitu secara berturutturut sebesar $27 \mathrm{mg}$ GAE/gram dan 36,07 mg GAE/gram. Peningkatan total senyawa fenol ini karena jahe mengandung senyawa fenolik gingerol dan shogaol yang berfungsi sebagai antioksidan (Tejasari, 2006).

Minuman instan formula 1 sampai dengan 6 merupakan minuman instan yang telah diberi perlakuan penambahan jahe dan ekstrak $S$. polycystum dan mengalami peningkatan total senyawa fenol seiring dengan bertambahnya konsentrasi ekstrak S. polycystum. Kadar total senyawa fenol dapat

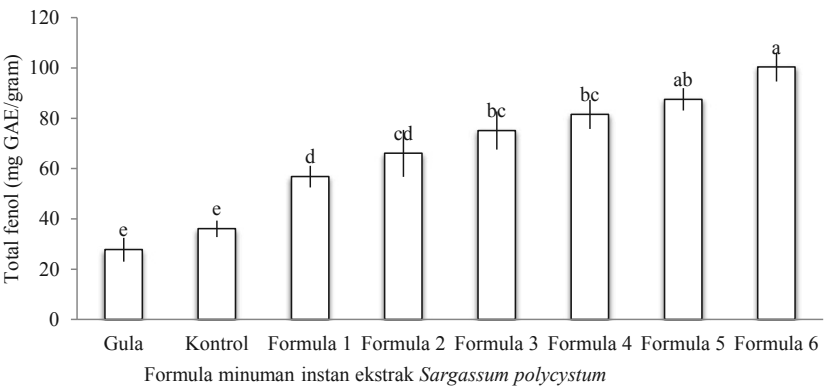

Gambar 3. Pengaruh formulasi penambahan ekstrak $S$. polycystum terhadap total fenol minuman instan (3000 ppm)

Keterangan: Tanda huruf yang berbeda menunjukkan ada beda nyata ( $\alpha$ $=0,05)$

berbeda-beda. Perbedaan nilai total fenol dalam setiap penelitian minuman jahe dan minuman berbasis Sargassum sp. dipengaruhi oleh bahan yang digunakan dalam pembuatan minuman. Zaelani dkk. (2012) melaporkan bahwa minuman teh $S$. fillipendula dengan perendaman jeruk nipis memiliki total senyawa fenol 42,4-4,85 mg/g. Sementara itu Febriyani (2013) menyatakan bahwa minuman herbal Sargassum sp. dengan penambahan 1 gram jahe memiliki nilai total fenol 0,07-0,08 mg/ml. Tangkeallo dan Widyaningsih (2014) menambahkan bahwa minuman jahe dengan formulasi penambahan ekstrak miana memiliki total fenol sebesar 25$45 \mathrm{mg} / \mathrm{g}$.

\section{Kadar Total Gula}

Hasil pengujian total gula minuman instan dengan penambahan ekstrak $S$. polycystum dapat dilihat pada Gambar 4. Berdasarkan analisis varian diketahui bahwa nilai total gula yang terkandung di dalam minuman instan dipengaruhi oleh variasi formula penambahan ekstrak $S$. polycystum ( $\mathrm{p}<0,05)$. Hasil uji HSD-Tukey menunjukkan bahwa total gula yang terkandung dalam minuman instan formula kontrol berbeda nyata $(\mathrm{p}<0,05)$ dengan minuman instan yang diberi penambahan ekstrak S.polycystum maupun minuman instan komersial. Nilai total gula minuman instan kontrol dan minuman instan komersial sebesar 87,17\% dan 95,78\%. Hal ini menunjukkan bahwa penambahan ekstrak $S$. polycystum mempengaruhi nilai total gula dalam minuman instan dimana semakin besar penambahan ekstrak S. polycystum menyebabkan nilai total gula semakin menurun. Menurut BSN (1996) serbuk minuman tradisional memiliki kandungan total gula maksimal 85\%. Minuman instan kontrol dan minuman instan komersial dalam penelitian ini tidak memenuhi standar SNI. Adapun minuman instan dengan penambahan ekstrak $S$. polycystum yaitu formula 1 sampai dengan 6 telah memenuhi standar SNI. 


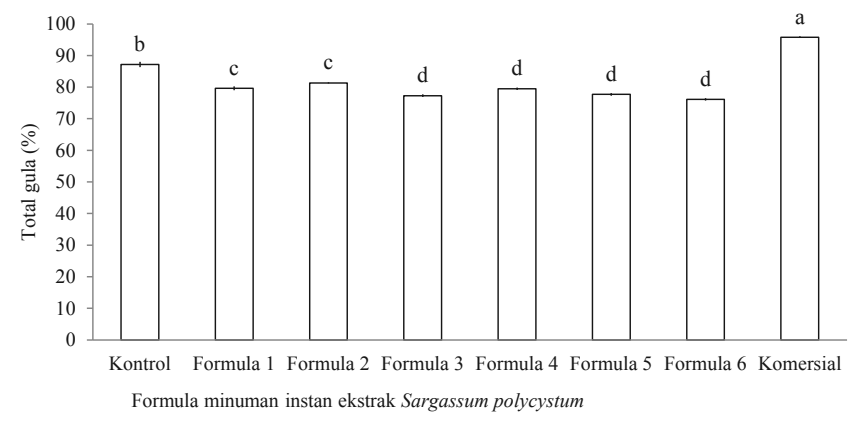

Gambar 4. Pengaruh formulasi penambahan ekstrak S.polycystum terhadap total gula minuman instan

Keterangan: Tanda huruf yang berbeda menunjukkan ada beda nyata ( $\alpha$ $=0,05$ )

\section{Kadar Air}

Menurut BSN (1996) serbuk minuman tradisional mengandung kadar air maksimal 3\%. Kadar air serbuk minuman instan dengan penambahan ekstrak $S$. polycystum dapat dilihat pada Gambar 5. Berdasarkan analisis varian diketahui bahwa kadar air minuman instan dipengaruhi oleh variasi formula penambahan ekstrak $S$. polycystum $(\mathrm{p}<0,05)$. Namun demikian, kadar air semua formula masih memenuhi standar SNI 01-4320-1996.

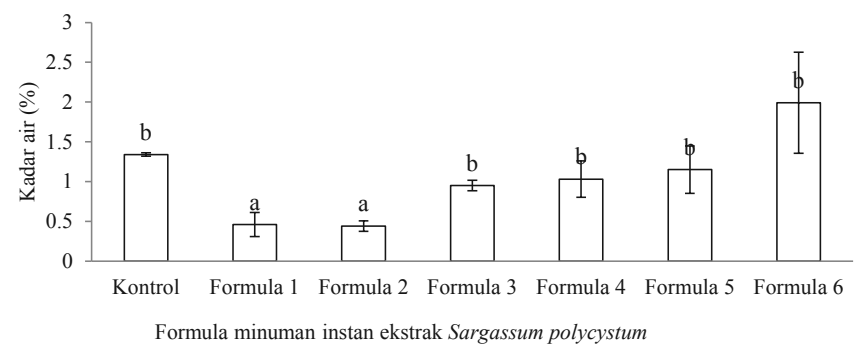

Gambar 5. Pengaruh formulasi penambahan ekstrak S.polycystum terhadap kadar air minuman instan

Keterangan: Tanda huruf yang berbeda menunjukkan ada beda nyata ( $\alpha$ $=0,05)$

Kadar air suatu bahan pangan sangat berpengaruh terhadap daya simpan dan kualitas suatu bahan pangan. Jika kadar air bahan terlalu tinggi, maka bahan tersebut akan rentan terserang kerusakan baik secara fisik, kimia, maupun mikroorganisme (Budijanto dkk., 2010). Menurut Schenck dan Hebeda (1992), higroskopisitas suatu produk akan meningkat seiring dengan peningkatan gula dalam bahan. Purnomo (1995) menyatakan bahwa, keadaan air dalam bahan pangan akan berubah-ubah sesuai dengan lingkungannya. Pada suatu titik kadar air minuman instan akan mengalami kejenuhan (Ibrahim dkk., 2014). Kadar air kritis ditandai jika suatu produk sudah mengalami kerusakan dan tidak dapat diterima lagi oleh konsumen (Budijanto dkk., 2010). Bahan pangan yang bersifat higroskopis dalam bentuk bubuk, faktor suhu dan kelembaban bahan pangan mempengaruhi tingggi rendahnya kadar air, sehingga akan mempengaruhi mutu produk (Syarief dan Halid, 1993).

\section{Kadar Abu}

Kadar abu minuman instan dengan penambahan ekstrak S. polycystum dapat dilihat pada Gambar 6. Kadar abu merupakan jumlah residu anorganik yang dihasilkan dari pengabuan/ pemijaran suatu produk(BSN, 2006). Berdasarkan hasil penelitian menunjukkan bahwa kadar abu minuman instan kontrol dan formula 1 telah memenuhi SNI dengan nilai kadar abu $0,06 \%$ dan $1,24 \%$. Penambahan ekstrak $S$. polycystum mempengaruhi kandungan abu minuman instan. Semakin besar penambahan ekstrak $S$. polycystum dalam minuman instan membuat kadar abu semakin tinggi.

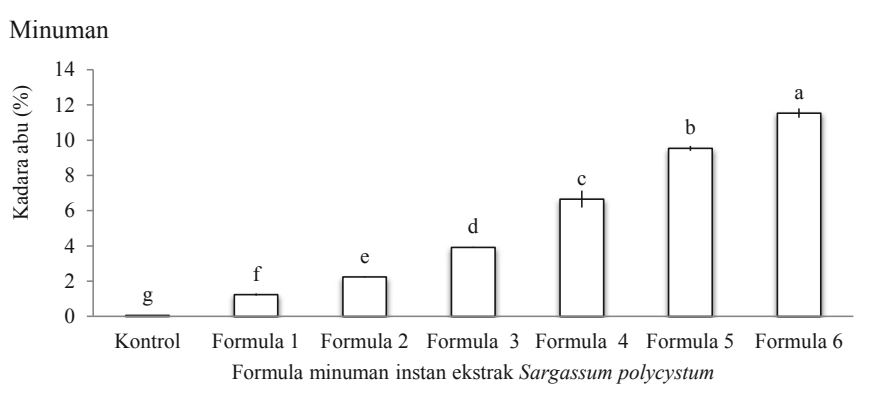

Gambar 6. Pengaruh formulasi ekstrak S. polycystum terhadap kadar abu minuman instan.

Keterangan: Tanda huruf yang berbeda menunjukkan ada beda nyata ( $\alpha$ $=0,05)$

Kadar abu semakin naik selain karena peningkatan kadar ekstrak $S$. polycystum juga dapat diakibatkan oleh semakin berkurangnya konsentrasi gula yang ditambahkan karena gula merupakan "humektan" yang mampu menurunkan kadar abu (Buckle dkk., 1987). Menurut Ibrahim dkk. (2014), suhu yang tinggi dalam pemanasan menyebabkan kandungan mineral dalam bahan berkurang. Kadar abu minuman instan dengan penambahan ekstrak S. polycystum selain dipengaruhi oleh adanya gula dan pemanasan, juga dipengaruhi oleh garam dan mineral yang ada pada rumput laut seperti $\mathrm{Mg}$ dan Ca (Zaelani dkk., 2012).

Formulasi minuman S. fillipendula dengan perendaman ekstrak jeruk nipis memiliki nilai kadar abu sebesar 9,6211,53\% (Zaelani dkk., 2012). Herliani (2009), menyebutkan kadar abu Sargassum sp. sebesar 30,9\%. Wibowo dan Fitriyani (2012), menambahkan bahwa minuman instan Euchema cottonii memiliki kadar abu 18-25\%. Tingginya kadar abu produk minuman dalam kedua penelitian ini dipengaruhi 
oleh penambahan rumput laut dalam minuman, sama halnya dengan tingginya kadar abu yang dalam penelitian ini juga dipengaruhi oleh penambahan ekstrak S. polycystum.

\section{Sifat Sensoris Minuman Instan}

Warna. Pengaruh formulasi minuman instan dengan penambahan ekstrak $S$. polycystum terhadap tingkat kesukaan warna minuman dapat dilihat pada Gambar 7. Nilai kesukaan konsumen berkisar antara 2,40 - 3,21 (tidak suka - suka). Uji Kruskal-Wallis menunjukkan bahwa banyaknya penambahan ekstrak S.polycystum mempengaruhi penilaian panelis terhadap warna $(\mathrm{p}<0,05)$. Hal ini dikarenakan semakin besar konsentrasi ekstrak $S$. polycystum maka semakin berwarna hijau sehingga warnanya kurang disukai panelis. Erminawati dan Naufalin (2014) menyebutkan dalam proses ekstraksi tanaman, komposisi, warna, aroma, dan rendemen yang dihasilkan akan dipengaruhi oleh jenis, ukuran dan tingkat kematangan bahan baku, jenis pelarut, suhu, waktu dan metode ekstraksi. Warna ekstrak yang didapatkan dari proses ekstraksi dipengaruhi senyawa bioaktif yang terdapat dalam alga cokelat (Grace, 2010).

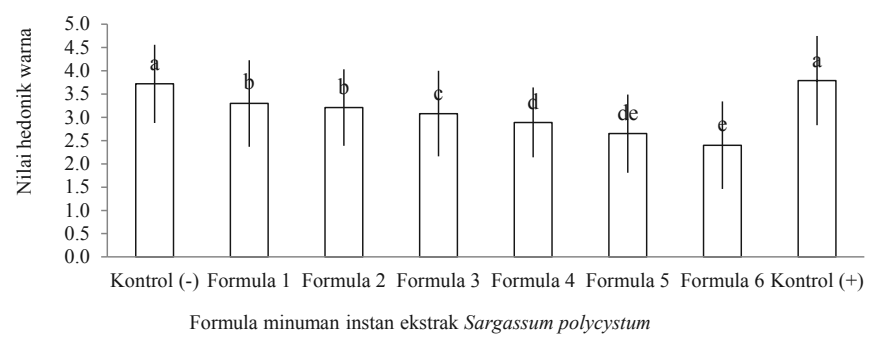

Gambar 7. Pengaruh formulasi penambahan ekstrak S. polycystum terhadap nilai hedonik warna minuman instan

Keterangan: Tanda huruf yang berbeda menunjukkan ada beda nyata ( $\alpha$ $=0,05$ )

Minuman instan kontrol (-) yang dibuat dari gula dan jahe tanpa penambahan ekstrak $S$. polycystum dan minuman kontrol $(+)$ berupa minuman instan komersial memiliki nilai meanrank 429,62 dan 434,55. Hasil ini menunjukkan bahwa minuman instan memiliki tingkat kesukaan warna yang tidak berbeda dengan produk minuman instan yang dipasarkan secara komersial, tetapi berbeda nyata $(\mathrm{p}<0,05)$ dengan minuman yang diberi ekstrak $S$. polycystum.. Berdasarkan pengujian hedonik menunnjukkan bahwa minuman kontrol (-) memiliki warna yang hampir sama dengan warna minuman kontrol $(+)$. Warna minuman ini dipengaruhi oleh variasi penambahan ekstrak S. polycystum. Semakin besar konsentrasi menyebabkan menurunnya tingkat kesukaan warna minuman yang didominasi oleh warna hijau.
Aroma. Tingkat penerimaan konsumen terhadap aroma minuman instan dengan penambahan ekstrak $S$. polycystum menunjukkan bahwa aroma minuman instan ini dipengaruhi oleh variasi penambahan ekstrak $S$. polycystum. Berdasarkan Gambar 8, terjadi penurunan tingkat kesukaan konsumen terhadap aroma karena penambahan ekstrak S. polycystum pada minuman instan. Analisis uji Kruskall-Wallys menunjukkan nilai meanrank setiap formulasi semakin menurun apabila konsentrasi penambahan ekstrak $S$. polycystum semakin besar. Semakin menurunnya nilai meanrank menunjukkan bahwa aroma minuman instan semakin tidak disukai. Hasil penelitian menunjukkan nilai hedonik aroma minuman instan dipengaruhi oleh variasi penambahan ekstrak $S$. polycystum. Semakin besar konsentrasi penambahan ekstrak S. polycystum menyebabkan menurunnya tingkat kesukaan aroma minuman instan yang didominasi oleh aroma khas rumput laut yang amis.

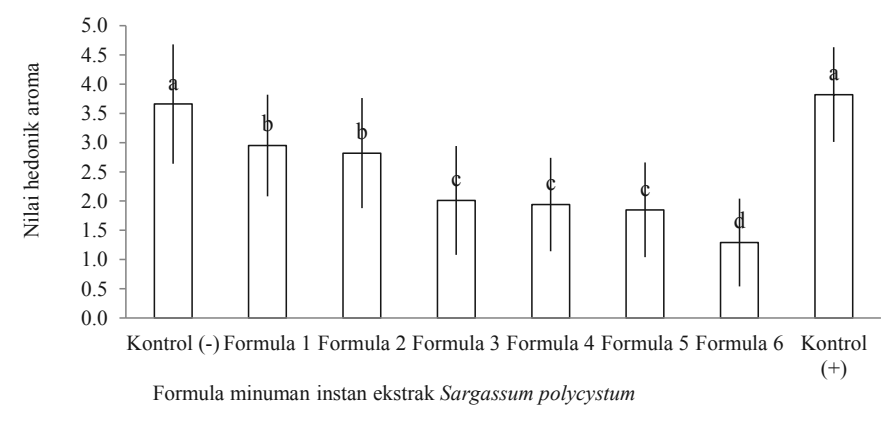

Gambar 8. Pengaruh formulasi penambahan ekstrak S. polycystum terhadap nilai hedonik aroma minuman instan

Keterangan: Tanda huruf yang berbeda menunjukkan ada beda nyata ( $\alpha$ $=0,05)$

Jahe yang terdapat dalam minuman instan bertujuan untuk menutupi aroma amis khas rumput laut namun aroma amis yang ditimbulkan oleh ekstrak $S$. polycystum masih tercium dalam minuman ini. Semakin tingginya aroma amis rumput laut menunjukkan bahwa aroma jahe tidak mampu menutupi aroma amis ekstrak $S$. polycystum sehingga menurunkan tingkat kesukaan konsumen. Berdasarkan pengujian hedonik minuman instan kontrol (-) dan minuman instan komersial (kontrol +) memiliki nilai meanrank tertinggi dibandingkan dengan minuman yang diberi perlakuan penambahan ekstrak $S$. polycystum. Uji lanjut Mann-Withney minuman instan kontrol (-) dan minuman instan komersial (kontrol + ) menunjukkan hasil yang tidak berbeda nyata ( $>0,05)$, yang berarti bahwa minuman instan ekstrak $S$. polycystum memiliki tingkat kesukaan aroma yang tidak berbeda dengan produk minuman instan yang dipasarkan (komersial). 
Rasa. Tingkat penerimaan konsumen terhadap rasa minuman instan dengan penambahan ekstrak $S$. polycystum dapat dilihat pada Gambar 9. Analisis data menggunakan metode Kruskall-Wallys menunjukkan nilai meanrank setiap formulasi semakin menurun apabila konsentrasi penambahan ekstrak $S$. polycystum semakin besar. Semakin menurunnya nilai meanrank menunjukkan bahwa rasa minuman instan semakin tidak disukai. Penurunan nilai hedonik rasa minuman instan dapat dikarenakan semakin menurunnya jumlah gula dalam produk dan juga disebabkan semakin meningkatnya ekstrak S. polycystum yang mempunyai rasa pahit.

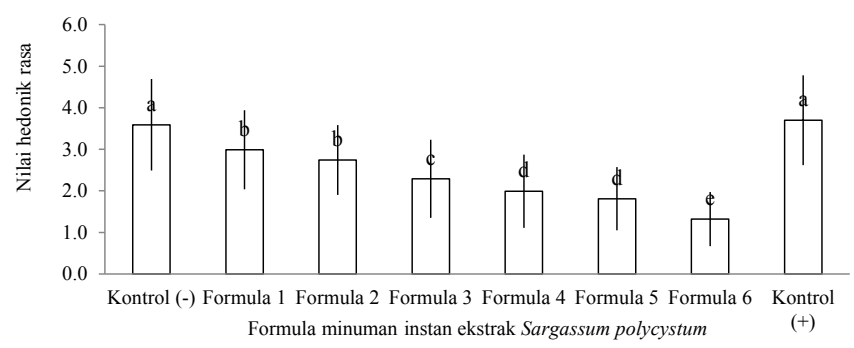

Gambar 9. Pengaruh penambahan ekstrak S. polycystum terhadap nilai hedonik rasa minuman instan

Keterangan: Tanda huruf yang berbeda menunjukkan ada beda nyata ( $\alpha$ $=0,05)$

Berdasarkan pengujian hedonik rasa minuman instan kontrol (-) dan kontrol (+) yaitu minuman instan komersial memiliki nilai meanrank tertinggi dibandingkan dengan minuman instan yang diberi penambahan ekstrak $S$. polycystum. Uji lanjut Mann-Withney minuman instan kontrol (-) dan minuman instan komersial menunjukkan hasil yang tidak berbeda nyata $(\mathrm{p}>0,05)$, yang berarti bahwa minuman instan kontrol (-) memiliki tingkat kesukaan rasa yang tidak berbeda dengan minuman instan yang beredar dipasaran (komersial).

Minuman instan kontrol (-) merupakan minuman yang paling banyak disukai oleh konsumen berdasarkan atribut warna, rasa dan aroma. Minuman instan kontrol (-) berwarna pucat kekuningan yang menyerupa warna minuman instan komersial yang telah ada dipasaran sehingga konsumen akan lebih tertarik untuk meminumnya. Menurut Winarno (2002), faktor warna cukup penting diperhatikan karena berpengaruh pada kesan dan penerimaan konsumen. Bahan makanan tidak akan dikonsumsi apabila memiliki warna yang tidak indah atau memberi kesan menyimpang dari warna seharusnya. Grace (2010), dalam pembuatan minuman rumput laut $E$. cottoni menyebutkan bahwa sesuai dengan warna aslinya (cokelat kemerahan) menyebabkan warna dari minuman sari rumput laut menjadi lebih keruh dan mengurangi tingkat kesukaan panelis. Formula minuman instan yang telah diberi penambahan ekstrak $S$. polycystum memiliki warna yang semakin menyimpang dibandingkan warna jahe instan umumnya yaitu membuat minuman menjadi berwarna hijau sehingga dengan melihat warna minuman minuman instan telah mengurangi kesukaan dan mempengaruhi penilaian konsumen terhadap atribut uji rasa dan aroma minuman instan.

\section{KESIMPULAN}

Semakin besar penambahan ekstrak $S$. polycystum pada minuman instan meningkatkan aktivitas antioksidan dan berkolerasai positif dengan nilai total fenol. Konsumen lebih menyukai minuman instan tanpa penambahan ekstrak $S$. polycystum. Semakin besar penambahan ekstrak $S$. polycystum maka tingkat kesukaan konsumen semakin menurun. Formula minuman instan terbaik didasarkan dari pengujian aktivitas antioksidan dan tingkat penerimaan konsumen yaitu minuman instan formula 3 dengan aktivitas antioksidan 40,02\%, total fenol 75,12 mg GAE/g, kadar total gula 77,28\%, kadar air 0,95\%, kadar abu 3,921\% dan mempunyai nilai kesukaan sebagai minuman instan yang agak disukai konsumen.

\section{UCAPAN TERIMA KASIH}

Penulis mengucapkan terima kasih kepada Direktorat Penelitian dan Pengabdian kepada Masyarakat Direktorat Jenderal Pendidikan Tinggi Kementerian Pendidikan dan Kebudayaan Republik Indonesia dan Lembaga Penelitian dan Pengabdian kepada Masyarakat Universitas Gadjah Mada yang telah mendanai penelitian ini melalui skim Hibah Penelitian Unggulan Perguruan Tinggi Universitas Gadjah Mada Tahun 2014 Nomor: LPPM-UGM/430/LIT/2014, tanggal 3 Maret 2014.

\section{DAFTAR PUSTAKA}

AOAC (1925). Official Method of Analysis. Association of Official Analytical Chemist (AOAC). Published by the Association of Official Analitycal Chemist. Washington DC, USA.

Balachandran, P., Pugh, D., Guoyi, M. dan Pasco, S. (2006). Toll-like receptor 2-dependent activation of monocytes by Spirulina polysaccharide and its immune enhancing action in mice. International Immunopharmacology 1(6): 1808-1814.

BSN (Badan Standardisasi Nasional) (2006). Penentuan Kadar Air Pada Produk Perikanan. SNI 01-235422006. Standar Nasional Indonesia (SNI). 
Buckle, K.A., Edwards, R.A., Fleet, G.H. dan Wooton. (1987). Ilmu Pangan. Terjemahan H. Purnomo dan Adiano. Universitas Indonesia Press, Jakarta.

Budijanto, S., Sitanggah, B.A., Silalahi, E.B. dan Mudiati, W. (2010). Penentuan umur simpan seasoning menggunakan metode accelerated shelf life testing (ASLT) dengan pendekatan kadar air kritis. Jurnal Teknologi Pertanian 11(2):71-77.

Chen, E., Viega, M.F. dan Rizutto, A.B. (1991). Cocrystallization an encapsulation process. Food Technology 2: 289-297.

Corazza, L., Mesomo, C., Agnes, P., Perez, E. dan Ndiaye, M. (2012). Ginger (Zingiber offinale) extracts obtained using supercritical $\mathrm{CO}_{2}$ and compressed propane kinetics and antioxidant activity evaluation. Journal of Supercritical Fluids 71: 102-109.

Daniel, W. (1989). Statistik Non Parametrik Terapan. Penerjemah Alex Tri Kantjono. Gramedia Pustaka, Jakarta.

Erminawati dan Naufalin, R. (2014). Sifat fisikokimia dan aktivitas antioksidan sarang semut (Myrmecodia pendans) sebagai pengawet alami pangan. Jurnal Teknosains Pangan 2(1): 115-123.

Fagbemi, N.T., Folashade, B.A., Ifesan, B.O. dan Badejo, A. (2013). Antioxidant properties of cold and hot water extracts of cocoa, hibiscus flower extract, and ginger beverage blends. Food Research International 52: 490495.

Febriyani, A. (2013). Formulasi Minuman Herbal Sargassum sp. dengan Berbagai Flavour Terhadap Aktivitas Antiosidan dan Tingkat Penerimaan Konsumen. Skripsi. Fakultas Pertanian. Universitas Gadjah Mada, Yogyakarta.

Gordon, S.P. dan Gordon. (1994). Contemporary Statistics a Computer Approch. Mc Graw-Hill Inc., New York.

Grace, S. (2010). Kandungan fosfor minuman sari rumput laut (Euchema cottonii). Pasific Journal 1(5): 792-795.

Herliani, N.E. (2009). Pengaruh Kalium Karbonat Terhadap Kualitas Natrium Alginat Sargassum sp. Skripsi. Fakultas Pertanian. Universitas Gadjah Mada, Yogyakarta.

Herold (2007). Formulasi Minuman Fungsional Berbasis Kumis Kucing (Orthosiphon aristatus Bl. Miq) yang didasarkan pada Optimasi Aktivitas Antioksidan, Mutu Citarasa dan Warna. Skripsi. Institut Pertanian Bogor, Bogor.
Ibrahim, A., Yuniantan dan Sriherfyna, F. (2014). Pengaruh suhu dan lama ekstraksi terhadap sifat kimia dan fisik pada pembuatan minuman sari jahe merah (Zingiber officinale) dengan kombinasi penambahan madu sebagai pemanis. Jurnal Pangan dan Agroindustri 3(2): 530-541.

Kang, C., Jin, B., Lee, H., Cha, M., Sohn. E., Moon, J., Park, C., Chun, S., Jung, E., Hong, J.S., Kim, J. dan Kim, E. (2010). Brown algae Eclonia cava attenuates type 1 diabetes by activating AMPK and AKT signaling pathways. Food and Chemical Toxicology 48: 509-516.

Kumar, M., Puja, K., Nitin, T., Mahendra, K., Vishal, G. dan Bhavanath, J. (2011). Minerals, PUFAs and antioxidant properties of some tropical seaweed from Saurashshtra coast of India. Journal of Applied Phycology 23: $797-$ 810 .

Kusumawati, P. (2007). Studi Karakteristik Antioksidan dan Sifat Organoleptik Minuman Herbal Sargassum sp. Skripsi. Fakultas Pertanian. Universitas Gadjah Mada, Yogyakarta.

Marsono, Y. (2008). Prospek pengembangan makanan fungsional. Jurnal Teknologi Pangan Gizi 7: 19-26.

Prasetyaningrum, U. dan Baskara, K.A. (2012). Aktivitas antioksidan, total fenol dan antibakteri minyak attiri dan oleoresin kayu manis (Cinnamomum burmannii). Jurnal Teknologi Sains Pangan 1(1): 24-31.

Pratiwi, T. (2013). Uji Aktivitas Metanolik Sargassum hystrix dan Euchema denticulatum dalam Menghambat $\alpha$-Amylase dan $\alpha$-Glukosidase. Skripsi. Fakultas Pertanian. Universitas Gadjah Mada, Yogyakarta.

Purnomo, H. (1995). Aktivitas Air dan Peranannya dalam Pengawetan Pangan. Universitas Indonesia Press, Jakarta.

Rohmatussolihat (2009). Antioksidan, penyelamat sel-sel tubuh manusia. BioTrends 4(1): 5-9.

Renhoran, M. (2012). Aktivitas Antioksidan dan Antimikrobia Ekstrak Sargassum polycystum. Skripsi. Institut Pertanian Bogor, Bogor.

Schen, R.E. dan Hebeda. (1992). Starch Hydrolisis Products: Worldwide Technology Production and Application. VCH., New York.

Septiana, T. dan Asnani, A. (2013). Aktivitas antioksidan ekstrak rumput laut Sargassum duplicatum. Jurnal Teknologi Pertanian 14(2): 79-86.

Setyaningsih, D., Apriyantono, A. dan Sari, M. (2010). Analisis Sensori Untuk Industri Pangan dan Agro. Institut Pertanian Bogor Press., Bogor. 
Sudarmadji, S., Haryono, B. dan Suhardi (1996). Analisa Bahan Makanan dan Pertanian. Liberty, Yogyakarta.

Syarief, R. dan Halid, H. (1993). Teknologi Penyimpanan Pangan. PAU Rekayasa Proses Pangan. Institut Pertanian Bogor, Bogor.

Tangkeallo, C. dan Widyaningsih, T. (2014). Aktivitas serbuk minuman instan berbasis miana kajian jenis bahan baku dan penambahan serbuk jahe. Jurnal Pangan dan Agroindustri 2(4): 278-284.

Tejasari, Z. (2006). Senyawa bioaktif rimpang jahe (Zingiber officinale Roscoe) meningkatkan respon sitolitik sel NK terhadap sel kanker darah K-562 in vitro. Jurnal Teknologi dan Industri Pangan 17: 97-108.

Vatai, T., Skerget M. dan Knez, Z. (2009). Extraction of phenolic compounds from elder berry and different grape marc varieties using organic solvents and supercritical carbon dioxide. Journal of Food Engineering 90(2): 246-254.
Wibowo, L. dan Fitriyani, E. (2012). Pengolahan rumput laut Eucheuma cottoni menjadi serbuk minuman instan. Jurnal Vokasi 8(2): 101-109.

Winarno, F. (2002). Kimia Pangan dan Gizi. Gramedia Pustaka Utama, Jakarta.

Zaelani, K., Kartikanigsih, H. dan Supirman. (2012). Pengaruh perbedaan $\mathrm{pH}$ perendaman asam jeruk nipis (Citrus auratifolia) dengan pengeringan sinar matahari terhadap kualitas kimia teh alga coklat (Sargassu fillipendula). THPi Student Journal 1(1): 46-52.

Zubia, M., Fabne, S.M., Kerjen, V., Lann, L.K., Povreav, S.V., Fauchon, M. dan Deslandes, E. (2009). Antioxidant and antitumoural activities of some Phaeophyta from Brittany coasts. Food Chemistry 116: 693-701. 